\title{
How far the Indian banking sectors are efficient?: An empirical investigation
}

\author{
Sudarshan Maity \\ The Institute of Cost Accountants of India, Kolkata, India, and \\ Tarak Nath Sahu \\ Department of Commerce, Vidyasagar University, Midnapore, India
}

\begin{abstract}
Purpose - Bank mobilizes savings and transforms it into credit for investments in various sectors, which helps the economy running. The purpose of this paper is to examine the efficiency of three bank groups in India with data spanning from 2009-2010 to 2018-2019.

Design/methodology/approach - The study uses data envelopment analysis for measuring the efficiency of the selected banks. It measures the efficiency both from the revenue dimension and from the supply-side dimension of financial inclusion.

Findings - The study finds that foreign banks on average are working efficiently far better than the publicsector and private-sector banks. It indicates that foreign banks in India are operating at $92.53 \%$ efficiency level, whereas private- and public-sector banks are operating at 90.20 and $86.04 \%$ efficiency levels, respectively. Further, the result of the Friedman test reveals that there is no significant difference in efficiency scores amongst these three bank groups. As major challenges, non-performing assets of the banking industry to be reduced by $15 \%$ as radial and $53.18 \%$ as slack.

Originality/value - One of the notable innovativeness of this study is that, unlike most of the previous studies that are mostly selected few banks and specific group, the present study may place itself as a unique inquiry in the domain of technical efficiency in macro concept by considering three major bank groups operating in India. An important contribution of the study is the classification of reasons behind the inefficiency, i.e. managerial or inappropriate scale size and further projections of input factors for the same level of output.
\end{abstract}

Keywords Technical efficiency, Data envelopment analysis, Financial inclusion, Commercial banks, Friedman test

Paper type Research paper

\section{Introduction}

Efficiency is always a matter of anxiety for running a business organization smoothly. The only efficient organization can give a good return and survive in the market for a longer period. When the banking system fails, the whole of a nations' payments system is in jeopardy, as all the sectors rely on banks for financing. From the customers' side, only efficient banks can offer better services due to their reasonable operational cost, and only then the regulator can achieve

\section{JEL Classification - G21, G29.}

(C) Sudarshan Maity and Tarak Nath Sahu. Published in Asian Journal of Economics and Banking. Published by Emerald Publishing Limited. This article is published under the Creative Commons Attribution (CCBY 4.0) licence. Anyone may reproduce, distribute, translate and create derivative works of this article (for both commercial and non-commercial purposes), subject to full attribution to the original publication and authors. The full terms of this licence may be seen at http://creativecommons. org/licences/by/4.0/legalcode.

This article is based on the previous publication of titled "Role of public sector banks towards financial inclusion during pre and post introduction of PMJDY: a study on efficiency review" authored by Maity and Sahu (2020) and "Assessing efficiency of private sector banks in India: an empirical investigation using DEA" authored by Maity et al. (2020). The authors acknowledged these two previous publications.

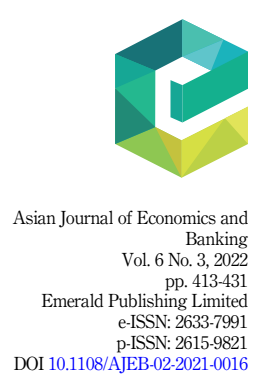


AJEB

6,3

the target of financial inclusion (Maity and Sahu, 2018b). Efficient banks are better able to compete because of their marginal operational costs. The health of a bank is necessary for an economy (Saha and Ravisankar, 2000; Swain et al., 2017; Maity, 2020). The Indian banking industry experienced multiple and quick changes (Maity and Sahu, 2019).

It has been well established that the development of financial or banking systems stimulates economic growth. Bankers are the distributors and custodians of liquid capital. The present study has considered all three banking groups of India: public-sector banks (PSBs), private-sector banks (PVBs) and foreign banks (FRBs). Only efficient banks can grow their business in the form of deposits and credit, reach the customer and, finally, guide policymakers in their decision-making process through developed decision-making tools. Efficient banks are better able to compete because of their lower operational costs.

Now banks are becoming much more competitive in all terms to have a global presence. The present study has considered all the 18 PSBs before the new merger of 10 banks into 4 taken place. As the mergers will take place from April 2020, researchers have considered the same as a separate entity, so that the amalgamated PSBs can take initiatives to minimize the input factors as well to enhance their efficiency level. The various previous studies conclude that PVBs or FRBs are performing far better than PSBs. Prior to the Covid-19 pandemic, the banking sector is already in a challenging position due to the mounting of non-performing assets (NPAs). Few PSBs are in much trouble due to the higher growth of NPAs. As a result, a number of banks are running at loss due to write-off the high volume of NPAs. Due to low performance of the PSBs, the regulators may have taken the decision of merger of one with another. Further, amongst the various institutions, PSBs hold a predominant position in the banking industry (Maity et al., 2020). Moreover, its participation in social banking activities is quite significant than the other participating banks (Martínez-Campillo et al., 2020; Agarwala et al., 2021). PSBs have been highly involved in the socio-economic development programmes (Sahu et al., 2020). In the present Indian banking market, when 10 PSBs are merged, PVB (Yes Bank) is reconstructed and further FRBs are not able to grow their business, the present study has investigated the technical efficiency (TE) together of PSBs, PVBs, and FRBs, so that a comparison can also be made between these three bank groups. An important contribution of the study is to find the reasons behind the inefficiency, i.e. managerial or inappropriate scale size and further classification of inefficient banks and projection of input factors.

\section{2. . Review of literature}

The banking sector is the backbone of all other industries, which provides finances from short term to long term to survive the other sectors. So without operating it efficiently, other sectors will also face the survival problem. Amidst the changing banking reforms, issues regarding banks' financial efficiency gained immense significance (Bhattacharyya et al., 1997; Sharma and Gupta, 2010; Paul and Das, 2015; Kaur and Gupta, 2015; etc.). However, banks not only had to attain their financial objectives to sustain in the ever-changing competitive market but also were required to achieve their social banking goals (Sahu et al., 2020). Bhattacharya et al. (1997) have assessed the efficiency of 70 commercial banks in India to analyse the banks' efficiency in the initial stages of liberalization policies. They find that PSBs as the most efficient followed by foreign banks and private banks for the period 19861991. In a study, Sharma and Gupta (2010) estimate the productivity growth, technological change, technical and scale efficiency (SE) of Indian banks for the period 1996-2006. The analysis indicates that the nationalized banks exhibit the best performance in scale economies, whereas private banks display the best performance in TE. Further, Paul and Das (2015) reveal that efficiency of PVBs is highest for the period 2000-2010. They study the efficiency level of 40 banks after the numerous market and regulatory initiatives. They point out that rapid application of advanced technology and efforts made towards marketing as the reasons behind the growing efficiency of private banks. In another study, Kaur and Gupta 
(2015) determine the efficiency scores of 57 Indian banks for the period 2009-2013, following the intermediation approach. The authors find SBI and its associates with the highest efficiency scores, followed by private banks. However, there is a wide gap between the efficiency of other nationalized banks and private banks. Rakshit (2019), on the assessment of 36 commercial banks for the year 2015-2016, finds that large banks have better profitability efficiency, whereas small banks reveal better marketability efficiency. The analysis also indicates that $80 \%$ of the banks are inefficient in terms of profitability and marketability.

While various traditional methods measure performance with financial data, data envelopment analysis (DEA) method measures performance that is characterized by nonfinancial data (Dyckhoff and Souren, 2020). The DEA application can be found in several services and industries both in the public and private sectors since applied by Chames et al. (1978). Here, researchers have surveyed the literature of DEA application to acknowledge that the DEA has been used as an efficiency assessment tool. In a study, Bhattacharyya et al. (1997) measure the efficiency of public, private and foreign-owned banks for a study period of 1986-1991. They included advances, investment, deposits as output variables and two types of expenses, i.e. operating and interest expenses as input variables. Using DEA, Maity and Sahu (2017) have measured the performance of SBI and associates for 2011-2016 with three output and four input variables. They have reported that before mergers took place, most of the associate banks of SBI operated at an efficient level, and the mergers will help to decrease unhealthy competition between SBI and its associate banks, mitigate the risk and better focus on defaulters. Applying a network slack-based DEA model, Martínez-Campillo et al. (2020) give insights into the financial and social efficiency of 26 Indian PSBs. The results indicate that the performance of PSBs in social efficiency $(74.96 \%)$ has been better than in financial efficiency $(71.97 \%)$. They also reveal a positive association between the social and financial performance of the PSBs. Wijesiri et al. (2019) study the efficiency of Indian PSBs in performing the dual roles of banking - social welfare and profiting through financial services - for the period 2011-2014 by using multi-activity DEA model. They find that the banks have been more efficient in social banking $(99.4 \%)$ than in its traditional banking activities (81.9\%). Maity and Sahu (2020) assess the efficiency of PSBs in promoting financial inclusion by comparing two periods, i.e. 2010-2014 and 2014-2018. The results demonstrate an increase in banks' efficiency after the introduction of PMJDY scheme (A National Mission for Financial Inclusion to ensure access to financial services), i.e. 2014-2018.

In a study, Saha and Ravisankar (2000) have suggested that in the Indian context, DEA could be a suitable approach towards measuring the efficiency of banks. Amongst the variables, deposits, and advances, etc., are output variables and branches and staff (in numbers), etc., are input variables. In their analysis, an attempt was made to quantify relative efficiency. The weights have been obtained using DEA for each bank by solving a linear objective function. Results of the analysis indicate that except for few exceptions, PSBs have in general improved their efficiency scores over the years 1992-1995. Despite this, a few banks like UTB, UCO, CBI, and SYND continued to be at the lower end of relative efficiency scales. Further, Burgstaller (2013) has measured efficiency in the regional banking market through DEA with three inputs and three output variables. In another study, Maity and Sahu (2018b) have measured the comparative efficiency of PSBs and PVBs toward financial inclusion. Using DEA, the study reveals that four banks were efficient under Charnes, Cooper and Rhodes (CCR) and 10 banks are efficient under Banker, Charnes and Cooper (BCC) model. Sinha and Jain (2015) in their study use owned funds, deposits, borrowings and employee cost as inputs and advances, investments and other income as outputs to measure potential gains from the merger of SBIs.

In a study, Kumar and Gulati (2008) have evaluated overall technical efficiency (OTE), pure technical efficiency (PTE) and SE of 27 Indian PSBs during 2004-2005. Besides this, the study explains the impact of environmental factors (like market share, asset quality, size, profitability, etc.) on the OTE of the PSBs. The average OTE of all the 27 banks was $88.5 \%$. Yue (1992) has
Efficiency of Indian banking sector 
AJEB 6,3 demonstrated the use of DEA to find out the relative efficiencies of 60 commercial banks in Missouri from 1984 to 1990. Two alternative models of DEA have been used for evaluation: CCR and the additive DEA model followed by window analysis of the efficiencies obtained. Das and Ghosh (2006) examined banks' performance during the post-reform period 1992-2002 in India. Medium-sized PSBs were found to perform at a higher level of TE. To arrive at this, they chose variables based on three approaches, namely intermediation, value-added and production approach. Variation in technical efficiencies was then observed about ownership, bank size, NPAs, capital adequacy ratio and quality of management.

In a study, Angelidis and Lyroudi (2006) have examined the productivity of 100 large Italian banks during 2001-2002 by using DEA. They employed DEA to find Malmquist indices of total productivity change, which is then put to use in examining the productivity of financial institutions of European Union countries. Feroze (2012) has employed DEA to assess the efficiency of district cooperative banks (DCBs) in Kerala during 2005-2009. The efficiency of DCBs was $74 \%$, and the magnitude of inefficiency was $26 \%$. Six DCBs are efficient and formed an efficient frontier amongst 26 DCBs. Valadkhani and Moffat (2009) have measured the efficiencies through DEA of 10 major financial institutions in Botswana during 2001-2006. Elyasiani and Mehdian (1995) have investigated the trends in TE and technological change for large and small U.S. commercial banks during 1979-1986. In their study, Pai et al. (2020) investigated which model is appropriate (CCR or BCC model) under the same business units and different business units. Mazumdar (2019) has examined the efficiency of banks during 2000-2001 to 2014-2015 through DEA. The results find that foreign banks, as a group, are the most efficient. Maity and Ganguly (2019) have analysed the trend in efficiency level during the pre- and post-demonetization phase from April 2014 to March 2018 by using DEA.

Other studies by Chander and Chandel (2010), Moslemi et al. (2019), Paradi and Zhu (2013), Wanke et al. (2019) and Maity et al. (2020) have also highlighted the importance of DEA model in measuring efficiency in the banking sector. Further, Lozano-Vivas et al. (2002) of EU countries; Eisazadeh (2019) in Middle Eastern and North African countries; Pastor et al. (1997) of 8 developed countries; Sufian et al. (2014) of Indian and Pakistani Banking sectors; Ruinan (2019) between U.S. and Canadian commercial banks and Sathye (2003), Sahu et al. (2020), Agarwala et al. (2021) of Indian context have applied DEA to measure efficiency. The study of Košak et al. (2009) examines the bank efficiencies amongst EU members. There is no doubt that a large number of studies have conducted to measure the efficiency of financial or banking institutions. However, measuring efficiency from the revenue point of view as well as service point of view is limited. By considering the research gap, researchers have considered one output variable from revenue perspective and another output variable from financial inclusion perspective of supplyside dimension. Here, researchers have considered maximum number of sample banks and variables to get appropriate results. From a methodological aspect, researchers find that there is significant diversity amongst studies in terms of input/output selection. The comparisons of efficiency scores obtained from the DEA model with other efficiency evaluation methods show mixed results. Given the importance of the banking sector and the focus on performance improvement, researchers believe that the basic DEA models, as well as their many extensions, would likely to play a more important role in measuring banks' efficiency.

\subsection{Objectives and hypotheses of the study}

In the Indian banking industry, PSBs, PVBs and FRBs are the major players with $80 \%$ of total branch coverage. And the objective of this study is to cover maximum number of sample banks to get appropriate results about the Indian Banking industry between the two crisis periods of 2008 and 2020. Considering the major players with maximum share of the market, the objective of this study is to examine the efficiency of PSBs, PVBs and FRBs. The following are specific objectives of the present study: 
(1) To investigate the TE and classify inefficient banks.

(2) To examine the radial, slack and projection of various input parameters.

Efficiency of Indian banking sector

Based on the previous discussion and research objectives, the null hypothesis $\left(\mathrm{H}_{0}\right)$ is that there is no significant difference in efficiency level between the three bank groups of PSBs, PVBs and FRBs.

\section{Data and methodology}

\subsection{Sample design}

The study considers the period of 10 years starting from 2009-2010 to 2018-2019. The study considers periods between the two crisis periods, starting from the post-financial crisis in 2007-2008. The financial crisis in 2007-2008 is also known as global financial crisis, which was a severe worldwide economic crisis. Further, it developed into an international banking crisis with the collapse of the investment bank Lehman Brothers on 15September 2008. So the objective of the present study is to investigate how the Indian banks are performing during the post-financial crisis period, i.e. after 2007-2008. In 2020, another crisis came, which all of us known as the Covid-19 pandemic that impacts every sector globally including the banking sector. So the ultimate objective of the present study is to measure the efficiency level between these two crisis periods and their trend in efficiency from 2009-2010 to 2018-2019.

The present study has considered all the 18 PSBs till March 2019 after the post-mergers of $\mathrm{BOB}, \mathrm{VIJ}$ and DENA earlier this year. Further, SBI merged its five associates and BMB with itself effective from April 2017. Before 2017, the number of PSBs was 27. The study considers anchor banks as a single unit including amalgamating banks, so that the study can suggest the new entity to take necessary initiatives bank-wise based on the results of the study. Amongst the 22 PVBs operating in India in March 2019, researchers have considered 20 PVBs. The rest two PVBs, Bandhan Bank Ltd. and IDFC First Bank Ltd., have started their operation from 2016. Researchers have considered the banks that are operating during the last 10 years, so these two PVBs have excluded from the analysis. Amongst the 46 FRBs operating in India as of March 2019, the study has considered 5 FRBs that covered $68.15 \%$ branch network, $68.4 \%$ of net interest and other income of total 46 FRBs.

For this purpose, secondary data have been collected from published records of various reports of Reserve Bank of India (RBI) like RBI Bulletin, Annual Reports of RBI, Banking Statistics - Basic Statistical Returns, etc., and annual reports of the individual sample banks as well. The study will be exploratory in nature. Data are gathered for an optimum period for accurate results. The requisite data for DEA analysis are on interest earned, interest expended, other income, branch, fixed assets and gross NPAs. The selected 43 banks covered $80 \%$ of the branch network of all the commercial banks (121,332 bank branches out of total 152,050 bank branches). Based on the selected 43 banks, a conclusion has been drawn in the Indian banking industry.

\subsection{Statistical and econometric tests used}

In the study of efficiency in the internal management of institutions, Farrell (1957) characterizes three different dimensions: allocative efficiency, economic efficiency and TE. The latter is the concept of efficiency more commonly used in the public sector. DEA is a non-parametric method of measuring the performance or efficiency of a decision-making unit (DMU) such as an organization or a public-sector agency. Efficiency is the ratio between an output and the factors that made it possible. It is very easy to compute this ratio if the DMU uses a single input to produce a single output, i.e. efficiency = (single output/ single input). 
AJEB 6,3
But having a single input and single output have a little practicality involved as it requires several inputs to produce several outputs, which makes the efficiency evaluation a difficult job. So, we require an output-to-input ratio value that takes account of all outputs and inputs. DEA is one such tool that evaluates the efficiency of DMU, which used multiple inputs to produce multiple outputs. Method of DEA introduced by Charnes et al. (1978) and Banker et al. (1984) to address the problem of efficiency measurement for DMUs with many inputs and many outputs has been applied. As introduced by Charnes et al. (1978), the efficiency measure for the DMUs can be calculated by solving the following mathematical programming problem assuming that there are " $n$ " DMUs, each with " $m$ " inputs and " $s$ " outputs:

$$
\max \frac{\sum_{r=1}^{s} v_{r} y_{r o}}{\sum_{i=1}^{m} u_{i} x_{i o}}
$$

subject to

$$
\begin{gathered}
\frac{\sum_{r=1}^{s} v_{r} y_{r j}}{\sum_{i=1}^{m} u_{i} x_{i j}} \leq 1 ;(j=1,2, \ldots, n) ; \\
u_{i}, v_{r} \geq 0
\end{gathered}
$$

where, $i=1,2, \ldots \ldots, m ; r=1,2, \ldots . . ., s ; \mathrm{y}_{r j}=$ output " $r$ " produced by DMU $j ; x_{i j}=$ input " $i$ " utilized by DMU $j$; $v_{r}=$ weight given to output $r ; u_{i}=$ weight given to input $j$. To evaluate each DMU's relative efficiency score, it transformed into a linear programming problem.

$$
\begin{gathered}
\max \sum_{\substack{r=1 \\
\text { subject to }}}^{s} v_{r} y_{r o} \\
\sum_{r=1}^{s} v_{r} y_{r j}-\sum_{i=1}^{m} u_{i} x_{i j} \leq 0 ;(j=1,2, \ldots, n) ; \\
\sum_{i=1}^{m} u_{i} x_{i j}=1 ; \\
u_{i}, v_{r} \geq 0
\end{gathered}
$$

To analyse the efficiency of DMUs, CCR model under constant returns to scale (CRS) assumption and BCC model under variable returns to scale (VRS) assumption have been used. Also, the SE can be derived by the ratio of OTE to PTE. With a real variable $\theta$ and a nonnegative vector $\lambda=\left(\lambda_{1}, \lambda_{2}, \ldots, \lambda_{n}\right)$ of variables, the formulation of input-oriented CCR model can be depicted as follows:

$$
\begin{gathered}
\min _{\theta, \lambda} \theta \\
\text { Subject to } \\
\theta x_{i o}-\sum_{j=1}^{n} \lambda_{j} x_{i j} \geq 0(i=1,2, \ldots, m) \\
\sum_{j=1}^{n} \lambda_{j} y_{r j} \geq y_{r o}(r=1,2, \ldots, s) \\
\lambda_{j} \geq y_{r o}(j=1,2, \ldots, n)
\end{gathered}
$$


The OTE equals to one indicates that these DMUs (i.e. banks) are efficient and lie on the efficient frontier under CRS assumption based on CCR model. Further, PTE equals to one also indicates that these DMUs are efficient and lie on the efficient frontier under VRS assumption based on BCC model. The present study considered the input-oriented model. The inputoriented models object at minimizing the inputs consumed by the DMUs for the same target of output levels.

The requirement of homogeneity is fulfilled by the units of branches, deposits and credit disbursement of the same business unit, in which case CCR can be applied. Another dilemma is whether to use the input orientation model (focusses on better utilization of the inputs) or to use the output orientation model (focusses on the targets and outputs achieved). It is always within our control to better utilize the resources or inputs, and hence, setting a target for inputs or performance is feasible. However, the outputs depend on many extraneous factors. Setting targets for outputs, therefore, is not feasible. Hence, the input-oriented CCR model measuring the OTE was found suitable (Pai et al., 2020). Researchers also decomposed the OTE into its non-additive mutually exclusive components of PTE and SE to distinguish the technical inefficiency into managerial inefficiency and scale inefficiency. The ratio of TE scores under the two assumptions provides a measure of $\mathrm{SE}$. Mathematically, $\mathrm{SE}=\frac{\mathrm{TE}_{\mathrm{crs}}}{\mathrm{TE}_{\mathrm{rs}}}$

The CCR model assumes CRS, so the efficiency frontier will be linear, and the BCC model assumes VRS, so its efficiency frontier is formed by the convex hull (Figure 1). If for the proportionate changes in all inputs, the output results vary by a different proportion, then there are VRS which can be classified as increasing returns to scale (IRS) and decreasing returns to scale (DRS). MaxDEA 5.2 statistical package has been used to measure the TE of banks through DEA. The DMU is called efficient when the score is 1 and all slacks are 0 (Cooper et al., 2006). A DMU is an inefficient or low-efficiency level for a score $<1$. For example, a value of 0.75 for a specific DMU indicates that $25 \%$ reduction of all inputs (while maintaining the output level) would be needed to reach the efficiency. The researchers have also examined the assumptions of "isotonicity" relations (Golany and Roll, 1989) amongst selected factors. Further, the Friedman test is a non-parametric statistics used to know the significant difference between groups. Additionally mean, quartiles, etc., are used. Quartile values are calculated to classify inefficient banks.

\subsection{Description of variables}

The selection of inputs has been determined on the basis that the efficiency measurement is focussed on the internal control and productivity of banks (Sealey and Lindley, 1977). In practice, the banks use various levels of different input resources to serve the customers. According to Smith (1997), the input and output in DEA model should be kept at limited to get accurate

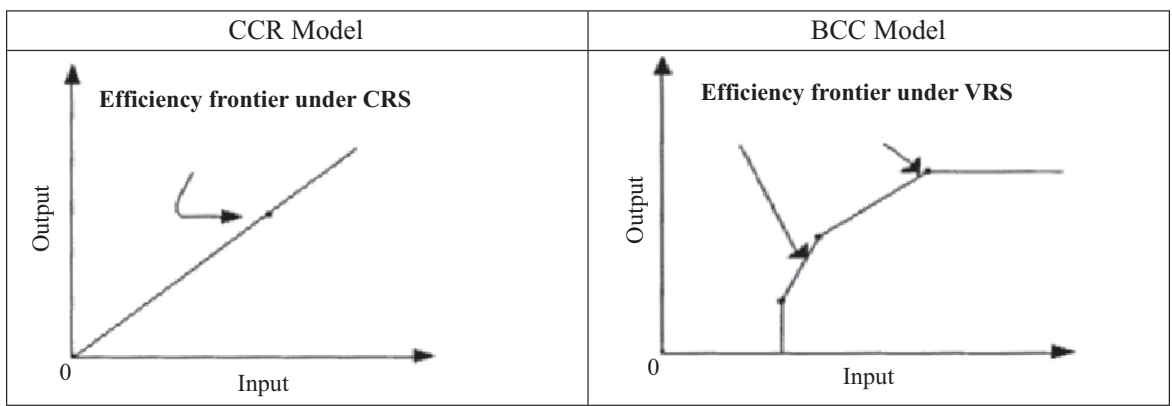

Source(s): Researchers'self-construction
Efficiency of Indian banking sector

Figure 1. Efficiency frontier: $\mathrm{CCR}$ and $\mathrm{BCC}$ 
AJEB 6,3 results. Based on the previous literature, majorly five dimensions of the banking operation such as assets, operational cost, loss from advance given (i.e. NPAs), income generation and financial inclusion are considered in the study. The output variables considered here are the net interest income and other income and secondly bank branches. The input variables considered here are the fixed assets, non-interest expenses and gross NPAs of individual selected banks. After a careful review of earlier literature and considering present research objectives, the study selected these input and output variables. Here, we would like to assert that the choice of the variables followed two criteria: relevance and availability (Maity, 2020).

3.3.1 Output variables. 3.3.1.1 Net interest income and other income. Banks earn interest from advance and pay interest on deposits. Rather considered both these as variables separately, net interest income is considered as output variables, which is measured as the difference between interest earned and interest expended (Das, 1997, 2000; Sathye, 2003; Mohan and Ray, 2004; Kumar and Gulati, 2008). Further, other than interest income, the bank also earns income from different sources which are also a large portion of banks' total income. This other income also added with the net interest income to get the actual income position of the respective banks. The previous studies by Saha and Ravisankar (2000), Mukherjee et al. (2002), Sathye (2003), Das et al. (2004), Chakrabarti and Chawla (2005), Kumar and Gulati (2008), Burgstaller (2013) and Sinha and Jain (2015) also used other income by banks as an output variable in their efficiency measure.

3.3.1.2 Bank branch. In Indian perspective, number of branches of a bank is playing a major role in financial inclusion (Kodan et al., 2011; Das and Guha, 2015; Maity and Sahu, 2018a). One of the main objectives of the government is to expand bank branches to achieve the target of financial inclusion. Further, the present study has considered the input-oriented model, i.e. minimization of input for the same level of output. And the target of banks is not to minimize the number of bank branches. By considering branch as a supply-side dimension of financial inclusion, the present study has considered branch as an output variable. The previous studies by Saha and Ravisankar (2000), Maity and Sahu (2017) and Maity and Sahu (2018b) have considered bank branch as an input variable.

The researchers have considered two output variables, one from maximization of revenue and another from financial inclusion perspective. The objective of this study is to investigate how much input can be reduced for the same level of output or how much output can be enhanced with the same input. With this respect, banks can fulfil their objectives of revenue maximization and cost minimization. On the other side, governments' objective of financial inclusion will also fulfil by maximization of supply-side dimension.

3.3.2 Input variables. 3.3.2.1 Operating expenses. Other than interest expenses on deposits, another major expense head is operating expenses. It includes all operational costs, namely employee costs, administrative costs, advertisement, rent, stationery, etc. This input variable selection is based on the previous studies of Bhattacharyya et al. (1997), Saha and Ravisankar (2000), Mukherjee et al. (2002), Sathye (2003), Chakrabarti and Chawla (2005), Ordia and Bhanawat (2018) and Sahu et al. (2020).

3.3.2.2 Fixed assets. The fixed asset is the other input variable that signifies the size of the business. It represents the size of banking business which makes revenue for the bank. This input variable is in line with the study of Saha and Ravisankar (2000), Das et al. (2004), Burgstaller (2013), Sahu et al. (2020), Maity et al. (2020).

3.3.2.3 Gross non-performing assets. Increase in NPAs stops banks to take expansion decisions, and it adjusts as expenses/losses with the revenue generated, and due to advances getting blocked, the credibility of banks decreases. According to Sharma and Chhabra (2017), it does not generate any income. In general, advances and loans given to its customers are assets. But, when the repayment of principal and interest is overdue for 90 days, such an asset is classified as NPA (RBI, Annual Report, 2000-2001). In line with the studies of Saha and Ravisankar (2000), Sathye (2003), Das and Ghosh (2006), Burgstaller (2013), Sinha and Jain 
(2015), Maity and Sahu (2017), Maity and Sahu (2019), Maity et al. (2020), present study also considers gross NPAs as an input variable.

\section{Analysis and findings}

Efficiency measurement is a basic part of the evaluation process of any business organization. It is essential to identify the correct method and variables to assess the performance of any financial institution. By considering the importance of DEA application, the present study measures the TE of the selected 43 banks followed by a comparison of efficiency between the three bank groups. Following this radial, slack and projections of the variables are measured. To analyse efficiency, we need to find an optimum level of output with the given input or optimum level of input to get the given output.

\subsection{Measurement of technical efficiency and classifications}

The descriptive statistics of all the variables can be obtained from Table 1 to know the characteristics of the data. Before going for analysing the data, the researchers have examined the assumptions of the "isotonicity" relationship (Golany and Roll, 1989) amongst the input and output variables, and the data satisfy the isotonicity assumptions as the Pearson correlation ranged from 0.8981 to 0.9959 as presented in Table 2 . The study analyses the TE both under CCR and BCC models to investigate the trend of efficiency level of all the 43 banks for the period from 2009-2010 to 2018-2019. Further with the mean efficiency of different groups, a comparison also made.

Classification of banks according to the efficiency score is important in the current situation when a major share of banks is operating at below the efficiency level. So, the researchers can understand their position. Further, banks also can take appropriate managerial decisions to improve their performance. According to the TE of the selected banks, this section further classifies the inefficient banks into different categories. From Table 3, we can see that amongst 18 PSBs, one single bank (UCO) is efficient under CCR model, and 10 more banks (ANDB, BOB, CNRB, CBI, CORP, IDIB, PSIB, PNB, SBI and SYND) are efficient under BCC model. Amongst 20 PVBs, six banks (CATH, CITYU, HDFC, NABL, TMBL and YESB) are efficient under CCR,

\begin{tabular}{llrrrr}
\hline Variables & Symbol & Mean & Standard deviation & Minimum & Maximum \\
\hline Net interest and other income & NIOI & 93.44 & 149.07 & 1.93 & 912.94 \\
No. of branches & BRN & 2382.69 & 3680.02 & 13.10 & 22689.60 \\
Fixed assets & FAS & 21.37 & 32.30 & 0.20 & 195.50 \\
Operating expenses & OEX & 43.89 & 72.73 & 1.00 & 457.93 \\
Gross NPAs & GNPA & 103.68 & 170.75 & 1.12 & 1014.26
\end{tabular}

Source(s): Calculated by researchers
Efficiency of Indian banking sector

\section{(n)}




\begin{tabular}{|c|c|c|c|c|c|c|c|}
\hline \multirow{6}{*}{$\begin{array}{l}\text { AJEB } \\
6,3\end{array}$} & No & DMU & OTE & PTE & $\mathrm{SE}$ & RTS & Benchmark \\
\hline & 1 & ALLA & 0.8841 & 0.9816 & 0.9006 & DRS & CITYU; UCO \\
\hline & 2 & ANDB & 0.9786 & 1 & 0.9786 & DRS & CITYU; NABL; UCO \\
\hline & 3 & BOB & 0.8456 & 1 & 0.8456 & DRS & CITI; CITYU \\
\hline & 4 & BOI & 0.8027 & 0.8808 & 0.9114 & DRS & CITI; CITYU \\
\hline & 5 & BOM & 0.7805 & 0.8479 & 0.9205 & DRS & CITYU; NABL; UCO \\
\hline \multirow[t]{37}{*}{422} & 6 & CNRB & 0.8481 & 1 & 0.8481 & DRS & CITI; CITYU \\
\hline & 7 & CBI & 0.7568 & 1 & 0.7568 & DRS & NABL; UCO \\
\hline & 8 & CORP & 0.9547 & 1 & 0.9547 & DRS & CITYU; TMBL; YESB \\
\hline & 9 & IDIB & 0.9122 & 1 & 0.9122 & DRS & CITI; CITYU \\
\hline & 10 & $\mathrm{IOB}$ & 0.7854 & 0.8260 & 0.9509 & DRS & CITYU; UCO \\
\hline & 11 & $\mathrm{OBC}$ & 0.8951 & 0.9271 & 0.9654 & DRS & CITI; CITYU \\
\hline & 12 & PSIB & 0.8738 & 1 & 0.8738 & DRS & CITYU; NABL; UCO \\
\hline & 13 & PNB & 0.8932 & 1 & 0.8932 & DRS & CITI; CITYU \\
\hline & 14 & SBI & 0.7916 & 1 & 0.7916 & DRS & CITI; CITYU \\
\hline & 15 & SYND & 0.8116 & 1 & 0.8116 & DRS & CITYU; NABL; UCO \\
\hline & 16 & UCO & 1 & 1 & 1 & CRS & - \\
\hline & 17 & UNI & 0.8479 & 0.9321 & 0.9097 & DRS & CITI; CITYU \\
\hline & 18 & UTB & 0.8252 & 0.9657 & 0.8545 & DRS & CITYU; NABL; UCO \\
\hline & 19 & AXIS & 0.9226 & 0.9752 & 0.9461 & DRS & CITI; CITYU; DBAG \\
\hline & 20 & CATH & 1 & 1 & 1 & CRS & - \\
\hline & 21 & CITYU & 1 & 1 & 1 & CRS & - \\
\hline & 22 & DCBB & 0.7169 & 0.7372 & 0.9725 & IRS & CITYU; HDFC \\
\hline & 23 & DHAN & 0.7629 & 0.7636 & 0.9991 & IRS & CATH; CITYU; NABL \\
\hline & 24 & FEDE & 0.8755 & 1 & 0.8755 & DRS & CITYU; TMBL; YESB \\
\hline & 25 & $\mathrm{HDFC}$ & 1 & 1 & 1 & CRS & - \\
\hline & 26 & ICICI & 0.9960 & 1 & 0.9960 & DRS & CITI; CITYU \\
\hline & 27 & IDBI & 0.9271 & 0.9337 & 0.9929 & DRS & CITI; CITYU \\
\hline & 28 & INDBL & 0.9713 & 0.9750 & 0.9962 & IRS & CITYU; HDFC \\
\hline & 29 & JKBL & 0.8477 & 0.8568 & 0.9894 & DRS & CITI; CITYU \\
\hline & 30 & KARNA & 0.7777 & 0.8432 & 0.9223 & DRS & CITYU; NABL; UCO \\
\hline & 31 & KARUR & 0.8491 & 0.8907 & 0.9534 & DRS & CITI; CITYU \\
\hline & 32 & KOTAK & 0.7905 & 0.8412 & 0.9397 & DRS & CITI; CITYU; DBAG; HDFC \\
\hline & 33 & LVBL & 0.7809 & 0.8388 & 0.9310 & DRS & CITYU; NABL; UCO \\
\hline & 34 & NABL & 1 & 1 & 1 & CRS & - \\
\hline & 35 & RBLB & 0.9534 & 1 & 0.9534 & IRS & CITYU; HDFC \\
\hline & 36 & SIBL & 0.8679 & 1 & 0.8679 & DRS & CITYU; NABL; UCO \\
\hline & 37 & TMBL & 1 & 1 & 1 & CRS & - \\
\hline & 38 & YESB & 1 & 1 & 1 & CRS & - \\
\hline & 39 & CITI & 1 & 1 & 1 & CRS & - \\
\hline & 40 & DBSB & 0.7448 & 0.8997 & 0.8278 & IRS & DBAG; NABL; TMBL \\
\hline & 41 & DBAG & 1 & 1 & 1 & CRS & - \\
\hline & 42 & HSBC & 0.9072 & 0.9077 & 0.9995 & IRS & CITI; CITYU; DBAG \\
\hline & 43 & STCB & 0.9743 & 0.9743 & 1.0000 & IRS & CITI; CITYU \\
\hline
\end{tabular}

Technical efficiency and benchmark of inefficient banks
Note(s): DRS = decreasing returns to scale; IRS = increasing returns to scale; and CRS = constant returns to scale

Source(s): Calculated by researchers

and 10 banks (CATH, CITYU, FEDE, HDFC, ICICI, NABL, RBLB, SIBL, TMBL and YESB) are efficient under BCC. Further, CITI and DBAG are efficient amongst the five FRBs both under BCC and CCR. Under CCR, PSBs are operating at 86.04\% level, PVBs are operating at $90.20 \%$ level and FRBs are operating at $92.53 \%$ level, i.e. input could be reduced by $13.96 \%$ for PSBs, $9.80 \%$ for PVBs and $7.47 \%$ for FRBs for the same level of output. A DMU may be scale inefficient if it exceeds the most productive scale size (thus experiencing DRS) or if it is smaller 
than the most productive scale size (thus having not taken the full advantage of IRS). Indeed, most of the inefficient banks present the DRS that can decrease their scales to possibly improve their efficiencies. According to the analysis, 17 PSBs are operating at DRS, and only UCO is operating under CRS. Under the PVBs, 10 PVBs are operating at DRS, six are operating under CRS and four are operating under IRS (DCBB, DHAN, INDBL and RBLB). Further, amongst the five FRBs, two are operating under CRS (CITI and DBAG) and three are operating under IRS (DBSB, HSBC and STCB). Almost all the PSBs are operating under DRS except UCO, which implies that these banks are not performing at the favourable position.

To classify the banks, the TE is considered under CCR which is more appropriate than BCC model in unitary evaluation of homogeneous units (Pai et al., 2020; Maity and Sahu, 2019). From the study, it has been observed that nine banks are technically efficient under CCR amongst 43 banks. Other than efficient banks, the other three categories are: "below average" with scores less than first quartile $\left(Q_{1}\right)$, "average" between $Q_{1}$ and third Quartile $\left(Q_{3}\right)$ and "marginally inefficient" with scores greater than $\mathrm{Q}_{3}$. The category below average banks comprises of those banks that have not been able to make optimized use of their resources. They might require substantial attention and improvements regarding the utilization of their resources. The supervisors should pay special heeds during the on-site inspection of these banks to understand the weaknesses in the banks and to develop an action plan to take care of such weaknesses as well as to help the bank to grow. These banks need to cut down their inputs to achieve the same level of output. This can be done by setting the banks in their respective reference set as benchmarks and thus deciding the course of action for improvements. Based on this assumption, eight banks, namely BOM, CBI, IOB, DCBB, DHAN, KARNA, LVBL and DBSB were categorized as below average-performing banks (Table 4). Of these, three are from PSBs, four are from PVBs and the last one is from FRBs. On the other hand, marginally inefficient banks are those that have performed fairly well and that are very close to the efficient frontier, thus requiring minor improvements in their utilization of resources. Although they cannot be set as benchmarks, they exhibit a high level of operating efficiency. But this observation does not exclude them from getting the attention of the supervisors and regulators; instead, a little bit of special attention can make them the leading banks amongst the group. Amongst the 34 inefficient banks, eight banks are

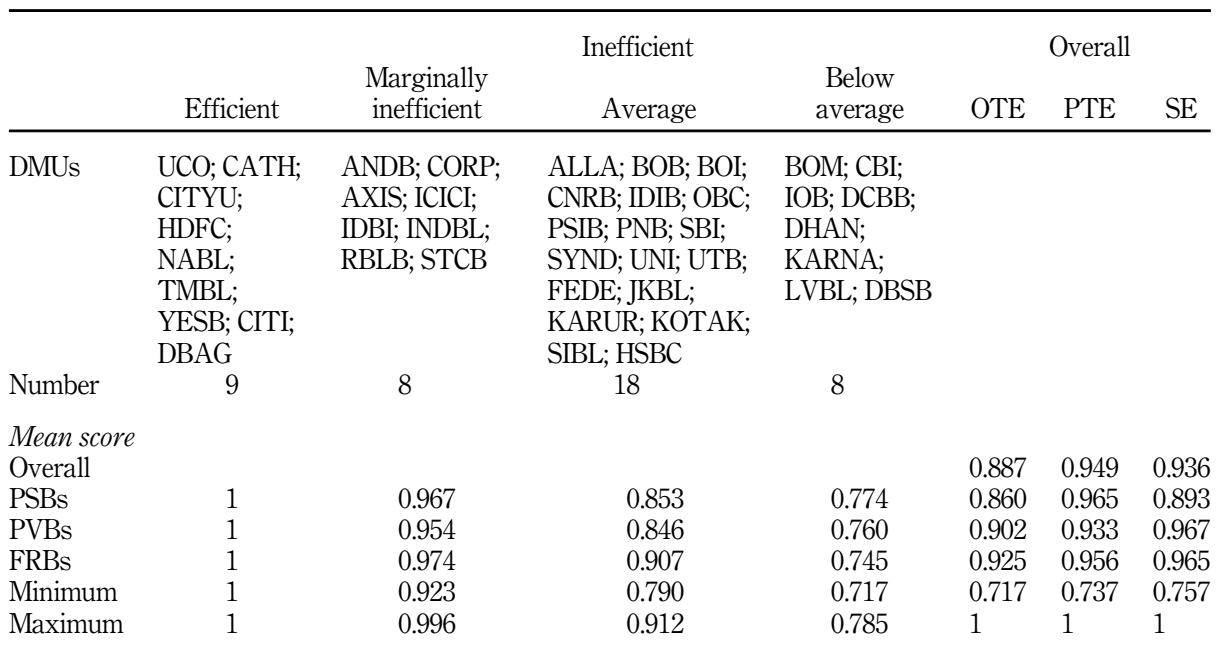

Source(s): Calculated by researchers
Efficiency of Indian banking sector 
AJEB 6,3

424

marginally inefficient (ANDB, CORP, AXIS, ICICI, IDBI, INDBL, RBLB and STCB) of which two are from PSBs, five are from PVBs and the last one is from FRBs. The other category is average, i.e. between marginally inefficient and below average. In total, 18 banks fall under this category of which 12 are from PSBs, five are from PVBs and the last one is from FRBs (Table 4). We admit that most PSBs (67\%) are operating at average efficiency levels. All these 18 banks also need special care by the management level as well as at the government level to find the weaknesses and cut down their inputs.

The study reveals that most benchmarks of inefficient PSBs are of PVBs and FRBs, due to their higher efficiency level. This result indicates the PSBs to follow the strategies of PVBs and FRBs. From the analysis, researchers observed that overall technical inefficiency (OTIE) is due to both pure technical inefficiency (PTIE) and scale inefficiency (SIE), i.e. poor input utilization and failure to operate at most productive scale size, respectively (Kumar and Gulati, 2008; Maity and Sahu, 2019; Agarwala et al., 2021). Table 4 shows that average PTE for the 43 banks has been observed to be 0.949 which implies that $5.1 \%$ (i.e. $1-0.949$ ) of 11.3 per cent (i.e. 1-0.887) of OTIE is due to managerial inefficiency, and the rest, i.e. $6.2 \%$ is due to scale size. Likewise, we may explain the same in the case of an individual bank or group-wise. In respect of PSBs, share of SIE > PTIE, whereas in the case of PVBs and FRBs, PTIE > SIE. This implies that the PSBs are mostly inefficient due to the scale size. Similarly, PVBs and FRBs are mostly inefficient due to the managerial inefficiency.

The present study further investigates the efficiency score for all 10 years of the study. The mean scores of all the 10 years for all the three bank groups are presented in Table 5. Further, the Friedman test is used to investigate the significant differences in efficiency scores between the three bank groups. The null hypothesis for this test is that there is no significant difference in efficiency ranks between the three groups. The difference amongst repeated measures is conducted and rendered a chi-square value of 2.811 , which is not significant as the $p$-value is greater than 0.05 . The result of the Friedman test in Table 6 indicates that there is no overall statistically significant difference between the mean ranks in

\begin{tabular}{lccccccccr}
\hline & \multicolumn{3}{c}{ OTE (mean score) } & \multicolumn{3}{c}{ PTE (mean score) } & \multicolumn{3}{c}{ SE (mean score) } \\
Year & PSBs & PVBs & FRBs & PSBs & PVBs & FRBs & PSBs & PVBs & FRBs \\
\hline $2009-2010$ & 0.762 & 0.745 & 0.716 & 0.957 & 0.894 & 0.991 & 0.797 & 0.837 & 0.721 \\
$2010-2011$ & 0.846 & 0.861 & 0.890 & 0.958 & 0.927 & 0.959 & 0.883 & 0.929 & 0.927 \\
$2011-2012$ & 0.894 & 0.862 & 0.947 & 0.963 & 0.922 & 0.993 & 0.929 & 0.935 & 0.953 \\
$2012-2013$ & 0.870 & 0.864 & 0.944 & 0.964 & 0.927 & 0.988 & 0.904 & 0.930 & 0.955 \\
$2013-2014$ & 0.821 & 0.871 & 0.929 & 0.934 & 0.936 & 0.932 & 0.880 & 0.931 & 0.997 \\
$2014-2015$ & 0.828 & 0.863 & 0.893 & 0.927 & 0.920 & 0.919 & 0.895 & 0.939 & 0.972 \\
$2015-2016$ & 0.801 & 0.890 & 0.865 & 0.922 & 0.939 & 0.884 & 0.870 & 0.947 & 0.974 \\
$2016-2017$ & 0.873 & 0.912 & 0.914 & 0.949 & 0.942 & 0.975 & 0.922 & 0.968 & 0.937 \\
$2017-2018$ & 0.825 & 0.902 & 0.855 & 0.939 & 0.932 & 0.918 & 0.880 & 0.968 & 0.918 \\
$2018-2019$ & 0.846 & 0.891 & 0.840 & 0.957 & 0.920 & 0.955 & 0.885 & 0.968 & 0.884 \\
Source(s): Calculated by researchers & & & & & & &
\end{tabular}

Table 5.

Mean efficiency scores

N

Table 6.

Results of the Friedman test

Source(s): Calculated by researchers 
the efficiency of the related groups. The test result indicates that 1.60, 2.10 and 2.30 are the mean ranks of PSBs, PVBs and FRBs, respectively.

\subsection{Radial, slack and projections}

One of the advantages of using DEA as a performance evaluation tool is not only that it gives away the level of efficiencies of DMUs by assigning them numerical values but also it unwraps the amount of radial and slacks present in inputs. After the necessary adjustment of radial and slacks, its projections (target values) were also measured. Radial is known as to whether all inputs need to be curtailed at equal proportions. Further, if any further reduction of any particular input is required to reach an efficiency level without the reduction of output, then the same is known as slacks (Kumar and Gulati, 2008). Table 7 presents the radial, slack and projection of the input factors of inefficient banks. From Table 7, we may interpret that suppose for ALLA, first this bank has to reduce all the input variables by $11.59 \%$ (Radial), and further to

\begin{tabular}{|c|c|c|c|c|c|c|c|}
\hline \multirow[b]{2}{*}{ DMU } & \multirow[b]{2}{*}{$\begin{array}{c}\text { Radial input } \\
(\%)\end{array}$} & \multicolumn{2}{|c|}{ Fixed assets } & \multicolumn{2}{|c|}{ Operating expenses } & \multicolumn{2}{|c|}{ Gross NPAs } \\
\hline & & $\begin{array}{l}\text { Slack } \\
(\%)\end{array}$ & $\begin{array}{l}\text { Projection } \\
(₹)\end{array}$ & $\begin{array}{c}\text { Slack } \\
(\%)\end{array}$ & $\begin{array}{c}\text { Projection } \\
\text { (₹) }\end{array}$ & $\begin{array}{c}\text { Slack } \\
(\%)\end{array}$ & $\begin{array}{l}\text { Projection } \\
\text { (₹) }\end{array}$ \\
\hline ALLA & 11.59 & 14.91 & 1510.28 & - & 2912.65 & 6.22 & 9684.58 \\
\hline ANDB & 2.14 & - & 871.64 & - & 2485.46 & 71.69 & 2772.80 \\
\hline BOB & 15.44 & 28.64 & 3293.01 & - & 9494.67 & 61.55 & 7685.24 \\
\hline BOI & 19.73 & 44.44 & 2016.74 & - & 5763.92 & 64.41 & 4529.65 \\
\hline BOM & 21.95 & 7.66 & 901.52 & - & 1738.64 & - & 5886.14 \\
\hline CNRB & 15.19 & 50.06 & 1950.13 & - & 5689.47 & 59.53 & 4783.23 \\
\hline CBI & 24.32 & 27.29 & 1590.76 & - & 3818.35 & 3.41 & 11883.03 \\
\hline CORP & 4.53 & - & 728.47 & - & 2316.75 & 74.02 & 1954.08 \\
\hline IDIB & 8.78 & 58.00 & 888.29 & - & 2597.67 & 55.11 & 2200.04 \\
\hline $\mathrm{IOB}$ & 21.46 & 21.08 & 1415.63 & - & 3104.97 & 35.78 & 7607.46 \\
\hline $\mathrm{OBC}$ & 10.49 & 37.98 & 918.13 & - & 2658.60 & 69.64 & 2182.27 \\
\hline PSIB & 12.62 & 42.50 & 428.48 & - & 1118.40 & - & 3101.94 \\
\hline PNB & 10.68 & 23.45 & 2844.79 & - & 8085.66 & 71.54 & 6233.36 \\
\hline SBI & 20.84 & 11.65 & 13198.28 & - & 36249.72 & 54.98 & 24525.24 \\
\hline SYND & 18.84 & 0.25 & 1389.14 & - & 3229.36 & - & 8416.64 \\
\hline UNI & 15.21 & 33.13 & 1556.67 & - & 4506.28 & 66.00 & 3695.45 \\
\hline UTB & 17.48 & 2.91 & 786.01 & - & 1645.66 & - & 5822.97 \\
\hline AXIS & 7.74 & - & 2612.13 & - & 8362.20 & 53.01 & 4151.12 \\
\hline DCBB & 28.31 & 42.29 & 85.83 & 3.62 & 299.73 & - & 188.13 \\
\hline DHAN & 23.71 & 18.27 & 99.35 & - & 259.96 & - & 260.38 \\
\hline FEDE & 12.45 & - & 362.11 & - & 1406.63 & 15.35 & 1185.54 \\
\hline ICICI & 0.40 & 25.05 & 4350.17 & - & 11241.49 & 75.32 & 5626.25 \\
\hline IDBI & 7.29 & 66.09 & 1272.71 & - & 3369.31 & 83.70 & 1925.85 \\
\hline INDBL & 2.87 & 38.48 & 613.85 & 3.23 & 2849.78 & - & 970.69 \\
\hline JKBL & 15.23 & 35.49 & 408.73 & - & 1138.57 & 55.95 & 815.09 \\
\hline KARNA & 22.23 & 6.60 & 260.90 & - & 702.85 & - & 929.32 \\
\hline KARUR & 15.09 & 5.55 & 290.56 & - & 823.14 & 30.32 & 627.20 \\
\hline KOTAK & 20.95 & - & 1059.13 & - & 3552.50 & - & 1693.06 \\
\hline LVBL & 21.91 & 32.94 & 120.38 & - & 364.51 & - & 729.09 \\
\hline RBLB & 4.66 & 22.87 & 122.44 & 16.84 & 541.04 & - & 208.16 \\
\hline SIBL & 13.21 & 34.58 & 245.74 & - & 801.13 & - & 871.54 \\
\hline DBSB & 25.52 & - & 39.42 & - & 370.46 & 58.13 & 136.49 \\
\hline HSBC & 9.28 & - & 830.57 & - & 2349.07 & 4.65 & 752.80 \\
\hline STCB & 2.57 & 34.49 & 1186.16 & - & 2890.89 & 80.79 & 927.77 \\
\hline
\end{tabular}

Efficiency of Indian banking sector

Source(s): Calculated by researchers 
AJEB 6,3 reach the efficient frontier for the identical level of output, it has to reduce FAS by $14.91 \%$ (slack) with a projection of ₹ $1,510.28 \mathrm{bn}$ and GNPAs by $6.22 \%$ (slack) with the projection of ₹9,684.58bn. In respect of DCBB, it has to reduce all inputs by $28.31 \%$ and further FAS by $42.29 \%$ with a projection of ₹ $85.83 \mathrm{bn}$ and OEX by $3.62 \%$ with a projection of ₹ $299.73 \mathrm{bn}$. With these reductions of input variables for the identical level of output, this bank will also reach the efficient frontier. We may interpret the same in respect of other banks also. The radial for the Indian banking industry is 15\% (approx.) for all inefficient banks, though it varies bank to bank. Further, the overall slack rate is $26.48 \%$ against FAS, $0.14 \%$ against OEX and $53.18 \%$ against GNPAs for all inefficient banks. It indicates that NPAs level should decrease with a maximum percentage compared to other input variables (Maity and Sahu, 2019; Maity et al., 2020).

\section{Discussion and conclusion}

A key challenge for policymakers is to find the optimum balance that can ensure the selection of appropriate variables or bank efficiency calculations with the relevant economic aspects of country-level data. Above all, future economic integration and prerequisite for developing a shield against a financial sector crisis require a better understanding of current bank performance and determinants. Our results significantly shed light on the dynamics of bank efficiency and the selection of appropriate variables considering both bank-level and government-specific objectives.

The objective of this study is to evaluate the extent of efficiencies of the PSBs, PVBs and FRBs operating in India. Also, the classification of these banks based on their efficiency scores is sought. Researchers also decomposed the OTE into its non-additive mutually exclusive components of PTE and SE. Further, radial and slacks are measured to project the input factors for the identical level of output. Amongst the groups, FRBs are most efficient followed by PVBs and PSBs. Though, Friedman test concludes that there is no overall statistically significant difference between the mean ranks in the efficiency of the three bank groups for the 10-year study period. The study finds that amongst the sample banks, nine banks are technically efficient and rest 34 banks are technically inefficient. Amongst the inefficient banks, eight banks are marginally inefficient, and these eight banks are close to the efficient frontier; 18 banks are with average inefficient and eight banks are with below average. Overall, the analysis shows that banks could save $11.3 \%$ of their total costs if they were operating efficiently. This study further implies that $5.1 \%$ of $11.3 \%$ of OTIE is due to managerial inefficiency and $6.2 \%$ is due to scale size.

According to Das and Ghosh (2006), medium-sized PSBs performed reasonably well and are more likely to operate at higher levels of TE. In line with the present study, Mazumdar (2019) has found that during 2000-2001 to 2014-2015, FRBs are more efficient than other groups. This result is consistent with the results of Bhattacharyya et al. (1997) that only two of 28 PSBs are found to be efficient in the final year of the sample period (1986-1991) though it contradicts that PSBs are most efficient, and PVBs are least efficient. Kumar and Gulati (2008) in their analysis also found seven banks were efficient of the 27 PSBs for the study period of 2004-2005, and Indian PSBs are operating at 88.5\% efficiency level. Maity and Sahu (2018b) have concluded that amongst the selected 20 banks, four banks have been globally efficient (CCR model) and six banks have been locally efficient (BCC model). Going in the same line, Maity and Ganguly (2019) during the pre and post-demonetization period, PVBs as a group is more efficient than PSBs group. The study partially contradicts with Sathye (2003) that the efficiency of PVBs as a group is paradoxically lower than that of PSBs and foreign banks in India. This result contradicts the results of Dhar (2012) that PSBs are the most efficient and PVBs are least efficient.

In reality, FRBs are covered with less number of branches and ignoring the various government social initiatives. Their objective is the maximization of revenue rather branch expansion in rural or slum areas, and they are located only in metropolitan areas for a higher volume of deposit and credit per account per branch. The other advantages are better 
managerial control or technology-driven products and services. Due to better managerial control, their level of NPA is also low compared to other bank groups. From the results of efficiency measures of the banks, it is observed that the PSBs are the least efficient ones followed by PVBs. To fulfil several government initiatives, PSBs are holding the prime role compare to PVBs and FRBs. Further, the focus of PSBs is more on account opening (Sahu et al., 2020), while PVBs are focussing on account opening with a volume of deposits and credits (Maity and Sahu, 2018b; Maity et al., 2020). The study also finds that PSBs are mostly inefficient due to the scale size rather than managerial inefficiency because of their rural presence compare to other groups. The study indicates that there is a need for both better utilization of resources and scale expansion. Further, improvement in the Indian Banking sector can be achieved by technological improvements.

A nation's development largely depends on the upliftment of the people at the lower strata of the pyramid. This largely includes people from the rural unorganized sector, who are generally meagre-earning labourers or small business owners (Sahu et al., 2020). Their long-term survival and sustenance depend on easy access to formal financial services and products. This necessitates that these financial institutions make use of the existing resources in the most efficient manner to parallelly meet its financial goals along with social obligations (Agarwala et al., 2021). Indian PSBs have been appreciated for its wider and active participation in nonprofit activities. The present study significantly adds to the existing literature with respect to the efficiency of such banks in attaining the targets of the social welfare schemes. The findings may be of use to Indian banking institutions and policymakers in developing countries and academics researchers in the area of banking efficiency. The major limitation is that the present study considers three bank groups and 10-year study period. The coverage of bank groups and the year of study period may be extended in the further study. The future study may be conducted after the Covid-19 pandemic over to measure how the pandemic impact on bank efficiency and a comparison with pre and post-pandemic situations. Though, further study may be conducted by considering cooperative banks, regional rural banks and small finance banks who are also the other major players in fulfilling the government's social objectives. By considering all these bank groups, a comparative study can also be undertaken to provide a larger picture of the Indian banking industry.

\section{References}

Agarwala, V., Sahu, T.N. and Maity, S. (2021), "Efficiency of public sector banks in achieving the goal of PMJDY and PMMY", International Journal of Economics and Business Research, (Accepted for publication).

Angelidis, D. and Lyroudi, K. (2006), "Efficiency in the Italian banking industry: data envelopment analysis and neural networks", International Research Journal of Finance and Economics, Vol. 5, pp. 155-165.

Banker, R.D., Charnes, A. and Cooper, W.W. (1984), "Some models for estimating technical and scale inefficiencies in DEA", Management Science, Vol. 30 No. 9, pp. 1078-1092.

Bhattacharyya, A., Lovell, C.A.K. and Sahay, P. (1997), "The impact of liberalization on the productive efficiency of Indian commercial banks", European Journal of Operational Research, Vol. 98 No. 2, pp. 332-345.

Burgstaller, J. (2013), "Bank office outreach, structure and performance in regional banking markets", Regional Studies, Vol. 47 No. 7, pp. 1131-1155.

Chakrabarti, R. and Chawla, G. (2005), "Banking efficiency in India since the reforms", Money and Finance, Vol. 9 No. 2, pp. 31-47.

Chander, R. and Chandel, J.K. (2010), "Financial viability of an apex co-operative credit institution - a case study of the HARCO bank", Asia-Pacific Business Review, Vol. 6 No. 2, pp. 61-70. 
AJEB 6,3

Charnes, A., Cooper, W.W. and Rhodes, E. (1978), "Measuring the efficiency of decision making units", European Journal of Operational Research, Vol. 2 No. 6, pp. 429-444.

Cooper, W.W., Seiford, L.M. and Tone, K. (2006), Introduction to Data Envelopment Analysis and its Uses with DEA-Solver Software and References, Springer, New York.

Das, A. (1997), “Technical, allocative and scale efficiency of public sector banks in India”, Reserve Bank of India Occasional Papers, Vol. 18 Nos 2-3, pp. 279-301.

Das, A. (2000), "Efficiency of public sector banks: an application of data envelopment analysis model", Prajnan: Journal of Social and Management Sciences, Vol. 28 No. 1, pp. 119-131.

Das, A. and Ghosh, S. (2006), "Financial deregulation and efficiency: an empirical analysis of Indian banks during the post reform period", Review of Financial Economics, Vol. 15 No. 3, pp. 193-221.

Das, T. and Guha, P. (2015), "A study on the differences in the banking parameters between pre- and post-financial inclusion periods: some evidence for India”, The IUP Journal of Bank Management, Vol. 14 No. 1, pp. 39-56.

Das, A., Nag, A. and Ray, S. (2004), Liberalization, Ownership, and Efficiency in Indian Banking: A Nonparametric Approach, Working Paper 2004-29, University of Connecticut, Connecticut.

Dhar, S. (2012), "Banking reforms for financial inclusion: performance of selected Indian banks", Amity Management Review, Vol. 2 No. 2, pp. 34-39.

Dyckhoff, H. and Souren, R. (2020), "Data envelopment methodology of performance evaluation", Performance Evaluation, Springer Briefs in Business. Springer, Cham, pp. 47-82.

Eisazadeh, S. (2019), "An analysis of bank efficiency in the Middle East and North africa", International Journal of Banking and Finance, Vol. 9 No. 4, pp. 28-47.

Elyasiani, E. and Mehdian, S. (1995), "The comparative efficiency performance of small and large US commercial-banks in the pre-deregulation and post-deregulation eras", Applied Economics, Vol. 27 No. 11, pp. 1069-1079.

Farrell, M.J. (1957), "The Measurement of productive efficiency”, Journal of the Royal Statistical Society, Vol. 120 No. 3, pp. 253-290.

Feroze, P.S. (2012), "Technical efficiency and its decomposition in District cooperative banks in Kerala: a data envelopment analysis approach", South Asian Journal of Marketing and Management Research, Vol. 2 No. 3, pp. 21-36.

Golany, B. and Roll, Y. (1989), "An application procedure for DEA”, Omega, Vol. 17 No. 3, pp. 237-250.

Kaur, S. and Gupta, P.K. (2015), "Productive efficiency mapping of the Indian banking system using data envelopment analysis", Procedia Economic and Finance, Vol. 25, pp. 227-238.

Kodan, A.S., Garg, N.K. and Kaidan, S. (2011), "Financial inclusion: status, issues, challenges and policy in northeastern region", The IUP Journal of Financial Economics, Vol. 9 No. 2, pp. $27-40$.

Košak, M., Zajc, P. and Zorić, J. (2009), "Bank efficiency differences in the new EU member states", Baltic Journal of Economics, Vol. 9 No. 2, pp. 67-89.

Kumar, S. and Gulati, R. (2008), "An examination of technical, pure technical, and scale efficiencies in Indian public sector banks using data envelopment analysis", Eurasian Journal of Business and Economics, Vol. 1 No. 2, pp. 33-69.

Lozano-Vivas, A., Pastor, J.T. and Pastor, J.M. (2002), “An efficiency comparison of European banking systems operating under different environmental conditions", Journal of Productivity Analysis, Vol. 18, pp. 59-77.

Maity, S. (2020), "Are private sector banks really more Efficient than public sector banks? - a comparative analysis using DEA", NMIMS Management Review, Vol. 38 No. 2, pp. 82-92.

Maity, S. and Ganguly, D. (2019), "Is demonetization really impact efficiency of banking sector - an empirical study of banks in India”, Asian Journal of Multidimensional Research (AJMR), Vol. 8 No. 3, pp. 315-327. 
Maity, S. and Sahu, T.N. (2017), "Pre-merger performance measures of State Bank of India and its associate banks using data envelopment analysis", Business Spectrum, Vol. 7 No. 2, pp. 16-26.

Maity, S. and Sahu, T.N. (2018a), "Bank Branch expansion and financial inclusion: evidence from selected commercial banks in India", Al-Barkaat Journal of Finance and Management, Vol. 10 No. 1, pp. 48-65.

Maity, S. and Sahu, T.N. (2018b), "Role of Public and Private Sector Banks in financial inclusion in India - an empirical investigation using DEA", SCMS Journal of Indian Management, Vol. 15 No. 4, pp. $62-73$.

Maity, S. and Sahu, T.N. (2019), "Is the efficiency of banks degenerating due to the mounting of nonperforming assets? An empirical investigation using DEA", Malaysian Management Journal, Vol. 23, pp. 65-86.

Maity, S. and Sahu, T.N. (2020), "Role of public sector banks towards financial inclusion during pre and post introduction of PMJDY: a study on efficiency review", Rajagiri Management Journal, Vol. 14 No. 2, pp. 95-105.

Maity, S., Sahu, T.N. and Biswas, D. (2020), "Assessing efficiency of private sectors banks in India - an empirical investigation using DEA", International Journal of Financial Services Management, Vol. 10 No. 2, pp. 138-155.

Martínez-Campillo, A., Wijesiri, M. and Wanke, P. (2020), "Evaluating the double bottom-line of social banking in an emerging country: how efficient are public banks in supporting priority and nonpriority sectors in India?”, Journal of Business Ethics, Vol. 162 No. 2, pp. 399-420.

Mazumdar, M.D. (2019), "An empirical study on measurement of efficiency of selected banks in India”, Indian Journal of Economics and Development, Vol. 7 No. 3, pp. 1-5.

Mohan, T.T. and Ray, S.C. (2004), Productivity Growth and Efficiency in Indian Banking: A Comparison of Public, Private, and Foreign Banks, Working Paper 2004-27, University of Connecticut, Connecticut.

Moslemi, S., Izadbakhsh, H. and Zarinbal, M. (2019), “A new reliable performance evaluation model: IFB-IER-DEA”, Opsearch, Vol. 56, pp. 14-31.

Mukherjee, A., Nath, P. and Pal, M.N. (2002), "Performance benchmarking and strategic homogeneity of Indian banks", International Journal of Bank Marketing, Vol. 20 No. 3, pp. 122-139.

Ordia, S. and Bhanawat, S.S. (2018), "Empirical analysis of financial health of scheduled commercial banks in India", Indian Journal of Accounting (IJA), Vol. 50 No. 1, pp. 69-77.

Pai, P., Khan, B.M. and Kachwala, T. (2020), "Data envelopment analysis - is BCC model better than CCR model? Case of Indian life insurance companies", NMIMS Management Review, Vol. 38 No. 1 , pp. 17-35.

Paradi, J.C. and Zhu, H. (2013), "A survey on bank branch efficiency and performance research with data envelopment analysis", Omega, Vol. 41 No. 1, pp. 61-79.

Pastor, J.M., Perez, F. and Quesada, J. (1997), "Efficiency analysis in banking firms: an international comparison”, European Journal of Operational Research, Vol. 98 No. 2, pp. 395-407.

Paul, J. and Das, K. (2015), "Efficiency of commercial banks in India: a non-parametric study using data envelopment analysis", Asian Journal of Research in Banking and Finance, Vol. 5 No. 6, pp. 37-48.

Rakshit, B. (2019), "Evaluating profitability and marketability efficiency: a case of Indian commercial banks", Global Business Review. doi: 10.1177/0972150918822569.

Ruinan, L. (2019), "Comparison of bank efficiencies between the US and Canada: evidence based on SFA and DEA", Journal of Competitiveness, Vol. 11 No. 2, pp. 113-129.

Saha, A. and Ravisankar, T.S. (2000), "Rating of Indian commercial banks: a DEA approach", European Journal of Operational Research, Vol. 124 No. 1, pp. 187-203. 
AJEB 6,3
Sahu, T.N., Agarwala, V. and Maity, S. (2020), "Social welfare through Mudra Yojana: how did the public sector banks perform in realizing the dream?", International Journal of Business Excellence, (Accepted for publication).

Sathye, M. (2003), "Efficiency of banks in a developing economy: the case of India", European Journal of Operational Research, Vol. 148, pp. 662-671.

Sealey, C.W. and Lindley, J.T. (1977), "Inputs, outputs, and a theory of production and cost at depository financial institutions", Journal of Finance, Vol. 32, pp. 1251-1266.

Sharma, S.C. and Chhabra, B. (2017), "The problem of NPAs: some facts relating to commercial banks in India", IUP Journal of Bank Management, Vol. 16 No. 1, pp. 48-61.

Sharma, S. and Gupta, S. (2010), "Malmquist productivity and efficiency analysis for banking industry in India”, International Journal of Business Excellence, Vol. 3 No. 1, pp. 65-76.

Sinha, R.P. and Jain, M.K. (2015), "Potential gains from merger: a study on SBI and its associates", The IUP Journal of Bank Management, Vol. 14 No. 2, pp. 56-60.

Smith, P. (1997), "Model misspecification in data envelopment analysis", Annals of Operations Research, Vol. 73 No. 1, pp. 233-252.

Sufian, F., Ashif, S.M.A. and Kamarudin, F. (2014), "Technical efficiency of single versus dual banking sectors: a comparative analysis of India and Pakistan", International Journal of Financial Services Management, Vol. 7 Nos 3/4, pp. 219-245.

Swain, R.K., Sahoo, M. and Mishra, A.P. (2017), Non-performing Assets of Scheduled Commercial Bank in India: Its Regulatory Framework, KIIT Journal of Management, Parikalpana, pp. 154-162, December.

Valadkhani, A. and Moffat, B. (2009), "A data envelopment analysis of financial institutions in Botswana”, Oxford Business and Economics Conference, Oxford, St. Hugh's College, Oxford University.

Wanke, P., Azad, A.K., Emrouznejad, A. and Antunes, J. (2019), “A dynamic network DEA model for accounting and financial indicators: a case of efficiency in MENA banking", International Review of Economics and Finance, Vol. 61, pp. 52-68.

Wijesiri, M., Martinez-Campillo, A. and Wanke, P. (2019), "Is there a trade-off between social and financial performance of public commercial banks in India? A multi-activity DEA model with shared inputs and undesirable outputs", Review of Managerial Science, Vol. 13 No. 2, pp. 417-442.

Yue, P. (1992), Data envelopment analysis and commercial bank performance: a primer with application to Missouri banks, Federal Reserve Bank of St. Louis Review, Vol. 74 No. 1, pp. 34-45.

\section{Corresponding author}

Tarak Nath Sahu can be contacted at: taraknathsahu1982@gmail.com 


\begin{tabular}{|c|c|c|c|}
\hline Sr. No & Name of the banks & Symbol & sector \\
\hline 1 & Allahabad Bank & ALLA & \\
\hline 2 & Andhra Bank & ANDB & \\
\hline 3 & Bhartiya Mahila Bank & $\mathrm{BMB}$ & \\
\hline 4 & Bank of Baroda & $\mathrm{BOB}$ & 431 \\
\hline 5 & Bank of India & BOI & \\
\hline 6 & Bank of Maharastra & BOM & \\
\hline 7 & Canara Bank & CNRB & \\
\hline 8 & Central Bank of India & CBI & \\
\hline 9 & Corporation Bank & CORP & \\
\hline 10 & Dena Bank & DENA & \\
\hline 11 & Indian Bank & IDIB & \\
\hline 12 & Indian Overseas Bank & IOB & \\
\hline 13 & Oriental Bank of Commerce & $\mathrm{OBC}$ & \\
\hline 14 & Punjab \& Sind Bank & PSIB & \\
\hline 15 & Punjab National Bank & PNB & \\
\hline 16 & State Bank of India & SBI & \\
\hline 17 & Syndicate Bank & SYND & \\
\hline 18 & UCO Bank & UCO & \\
\hline 19 & Union Bank of India & UNI & \\
\hline 20 & United Bank of India & UTB & \\
\hline 21 & Vijaya Bank & VIJ & \\
\hline 22 & Axis Bank Limited & AXIS & \\
\hline 23 & Catholic Syrian Bank Limited & CATH & \\
\hline 24 & City Union Bank Limited & CITYU & \\
\hline 25 & DCB Bank Limited & DCBB & \\
\hline 26 & Dhanlaxmi Bank Limited & DHAN & \\
\hline 27 & Federal Bank Limited & FEDE & \\
\hline 28 & HDFC Bank Limited & $\mathrm{HDFC}$ & \\
\hline 29 & ICICI Bank Limited & ICICI & \\
\hline 30 & IDBI Bank Limited\# & IDBI & \\
\hline 31 & IndusInd Bank Limited & INDBL & \\
\hline 32 & Jammu \& Kashmir Bank Limited & JKBL & \\
\hline 33 & Karnataka Bank Limited & KARNA & \\
\hline 34 & Karur Vysya Bank Limited & KARUR & \\
\hline 35 & Kotak Mahindra Bank Limited & KOTAK & \\
\hline 36 & Lakshmi Vilas Bank Limited & LVBL & \\
\hline 37 & Nainital Bank Limited & NABL & \\
\hline 38 & RBL Bank Limited & RBLB & \\
\hline 39 & South Indian Bank Limited & SIBL & \\
\hline 40 & Tamilnad Mercantile Bank Limited & TMBL & \\
\hline 41 & Yes Bank Limited & YESB & \\
\hline 42 & Citibank & CITI & \\
\hline 43 & DBS Bank India Limited & DBSB & \\
\hline 44 & Deutsche Bank Ag & DBAG & Table A1. \\
\hline 45 & Hongkong and Shanghai Banking Corporation Limited & $\mathrm{HSBC}$ & Name of banks and \\
\hline 46 & Standard Chartered Bank & STCB & their symbols \\
\hline
\end{tabular}

